Original Research Article

\title{
The hypolipidemic activity of ethanolic extract of seed kernel of Caesalpinia bonducella fleming on serum lipids and atherogenesis in albino rats fed with high fat diet
}

\author{
Gayatri Sarma $^{1 *}$, Swarnamoni Das ${ }^{2}$
}

\begin{abstract}
${ }^{1}$ Department of Pharmacology, Assam Medical College and Hospital, Dibrugarh, Assam, India

${ }^{2}$ Department of Pharmacology, Katihar Medical College, Karimbagh, Bihar, India
\end{abstract}

Received: 09 November 2017 Revised: 12 December 2017 Accepted: 04 January 2018

\begin{abstract}
*Correspondence to:
Dr. Gayatri Sarma,

Email: dr.gayatrisarma@ yahoo.co.in
\end{abstract}

Copyright: (C) the author(s), publisher and licensee Medip Academy. This is an openaccess article distributed under the terms of the Creative Commons Attribution NonCommercial License, which permits unrestricted noncommercial use, distribution, and reproduction in any medium, provided the original work is properly cited.

\begin{abstract}
Background: An increase in the incidence and prevalence of hyperlipidemia in India has led to an increased demand for drugs with a lipid lowering potential. Thus, the present study was undertaken to evaluate the hypolipidemic activity of ethanolic extract of seed kernel of Caesalpinia bonducella Fleming (EESKCB) in albino rats fed with high fat diet.

Methods: The extract was daily administered to healthy adult albino rats of either sex, fed with high fat diet for a period of 60 days. At the end of 60 days, i.e. on the 61st day, serum cholesterol, serum triglyceride, serum low density lipoprotein cholesterol, serum high density lipoprotein cholesterol, atherogenic index, the body weights of the rats and the serum levels of malondialdehyde (MDA) and catalase were estimated. Phytochemical analysis of the plant extract was also carried out. For statistical analysis, the methods employed were One-way ANOVA, Dunnett's multiple comparison test and Student's ' $t$ ' test (Paired). Values of $\mathrm{p}<0.05$ were considered significant.

Results: The test drug brought about significant $(\mathrm{p}<0.05)$ decrease in the raised levels of all the lipid parameters except the High density lipoprotein cholesterol. There was also a significant $(\mathrm{p}<0.05)$ increase in the serum levels of catalase and a significant $(p<0.05)$ reduction in the serum levels of MDA in the test drug treated group. The test drug also significantly $(\mathrm{p}<0.05)$ inhibited the rise in body weights of the rats.

Conclusions: From this study, it can be said that the seed kernel of Caesalpinia bonducella Fleming has significant hypolipidemic activity.
\end{abstract}

Keywords: Caesalpinia bonducella, Ethanolic extract, High fat diet, Hyperlipidemia, Hypolipidemic effect

\section{INTRODUCTION}

Hyperlipidemia refers to a condition that is characterised by increased levels of lipids, mainly total cholesterol, triglycerides, low density lipoprotein cholesterol and decreased levels of high density lipoprotein cholesterol in blood. ${ }^{1}$ Hyperlipidemia contributes to atherosclerosis which in turn leads to coronary artery disease, cerebrovascular disease, peripheral vascular disease and the like. ${ }^{2}$ The most commonly used drugs in the treatment of hyperlipidemia, the statins, are associated with several adverse effects. ${ }^{3}$ Hence, herbs and herbal drugs have been gaining increasing popularity worldwide as an alternative therapy in the management of hyperlipidemia. ${ }^{4}$

Caesalpinia bonducella Fleming, also known as Fever nut or Bonduc nut, is a prickly herb distributed all over India, especially in the Andaman and Nicobar Islands. All parts of the plant have been in use in traditional medicine. ${ }^{5}$ The plant has been reported to possess antidiabetic and antihyperlipidemic, abortifacient, antioxidant, analgesic, antiinflammatory, antifilarial, anticonvulsive, antibacterial, antidiarrhoel, antimalarial, antipyretic, antifungal, antitumor, antiulcer, antipsoriatic, 
immunomodulatory, anticataract, anthelmintic and anticancer activities. ${ }^{6}$ Literature reviews have indicated that although the antihyperlipidemic potential of the seed extract of this plant on diabetes-induced hyperlipidemia have been documented, no studies of the seed kernel extract of the plant on high fat diet-induced hyperlipidemia has been conducted so far. As such, the present study was aimed at evaluating the action of ethanolic extract of seed kernel of Caesalpinia bonducella Fleming on serum lipids and atherogenesis in albino rats fed with high fat diet.

\section{METHODS}

\section{Collection of plant material and extraction}

The seeds of Caesalpinia bonducella Fleming were collected from the local market in Dibrugarh in the months of June to August. Authentication of the plant material was done by Dr. L.R. Saikia, Professor, Department of Life Sciences, Dibrugarh University, Dibrugarh. A voucher specimen (No. DU/LS/212) was deposited at the Department of Life Sciences, Dibrugarh University.

Manual separation of the seed kernels of Caesalpinia bonducella Fleming from the outer seed shell was first carried out. The seed kernels were then air dried, powdered $(1200 \mathrm{~g})$ and ethanolic extracts were prepared using $90 \%$ ethanol by percolation method. ${ }^{7}$ The extract was evaporated to dryness in a vacuum desiccator to obtain a final yield of $133.5 \mathrm{~g}$ of the extract $(11.1 \% \mathrm{w} / \mathrm{w})$.

\section{Priliminary phytochemical analysis}

The ethanolic extract of seed kernel of Caesalpinia bonducella Fleming (EESKCB) was subjected to phytochemical analysis as per the standard methods. ${ }^{8}$

\section{Animals}

The study was carried out in healthy adult albino rats (Rattus norvegicus) of either sex (200-250g each). They were procured from Chakraborty enterprises, Kolkata and were taken care of as per the guidelines of the Committee for the Purpose of Control and Supervision of Experiments on Animals (CPCSEA). Permission from the Institutional Animal Ethical Committee for laboratory use of animals (Registration no: 634/02/a/CPCSEA; dated 19/05/2002) was duly obtained.

\section{Acute toxicity study}

Acute oral toxicity test for the ethanolic extract of seed kernel of Caesalpinia bonducella (EESKCB) was carried out as per OECD Guidelines $425 .^{9}$ Due to availability of data regarding the nontoxicity of the extract (EESKCB) at $2000 \mathrm{mg} / \mathrm{kg}$ when administered orally, the limit test at $2000 \mathrm{mg} / \mathrm{kg}$ was performed. ${ }^{10}$

One-tenth of the maximum dose tested was decided to be considered for the studies. ${ }^{11}$

\section{Chemicals used}

Simvastatin was obtained from IPCA Laboratories, Mumbai. Diagnostics kits for estimation of serum total cholesterol, triglycerides, high density lipoprotein cholesterol were purchased from Sigma Diagnostics (India) Pvt. Ltd., Baroda. All other chemicals and solvents of analytical grade used in the study like thiobarbituric acid, hydrogen peroxide, ferric chloride etc. were obtained from Sigma-Aldrich India, Bangalore. Coconut oil and vanaspati ghee used for preparation of high fat diet were obtained from Marico Industries Ltd., Mumbai and Ruchi Industries, Mumbai respectively.

\section{Method of preparation of high fat diet}

Edible coconut oil and vanaspati ghee were procured from the market and a mixture of the two was prepared in a ratio of $2: 3 \mathrm{v} / \mathrm{v}$ respectively. ${ }^{12}$

\section{Experimental design for antihyperlipidemic study ${ }^{13}$}

The experiment was carried out for a period of 8 weeks i.e. 60 days. For this purpose, 24 healthy albino rats of either sex were allowed to acclimatize to the laboratory environment for one week before starting the experiment. The animals were weighed, numbered and randomly divided into four groups of 6 animals each.

- Group A- Normal Control: Received Normal Saline at a dose of $10 \mathrm{ml} / \mathrm{Kg} /$ day. ${ }^{14}$

- Group B-Hyperlipidemic Control: Received high fat diet at a dose of $10 \mathrm{ml} / \mathrm{Kg} /$ day.

- $\quad$ Group C-Hyperlipidemic Test: Received high fat diet at a dose of $10 \mathrm{ml} / \mathrm{Kg} /$ day and EESKCB at a dose of $200 \mathrm{mg} / \mathrm{Kg} /$ day.

- Group D- Hyperlipidemic Standard: Received high fat diet at a dose of $10 \mathrm{ml} / \mathrm{Kg} /$ day and Simvastatin at a dose of $1.8 \mathrm{mg} / \mathrm{Kg} /$ day. ${ }^{15}$

The drugs were administered to the animals in the doses given above orally, once daily, for 8 weeks by means of intragastric feeding tube.

At the end of the 60 days, i.e. on the $61^{\text {st }}$ day, the body weights of the animals were recorded again. All the animals were kept fasting for 18 hours and blood samples were collected from the orbital sinus of each rat under all aseptic and antiseptic measures. ${ }^{16}$ Serum from the blood after clotting was collected and centrifuged for 10 minutes at $3000 \mathrm{rpm}$ for assessing the various parameters of lipid profile as also the status of antioxidant activity in blood.

\section{Weight observation}

A standard electronic weight machine (Precision Electronic Instrument's Company, Goldtech measuring scale) was used to record the body weight of the animals. Proper care was taken not to hurt the animals during handling. Body weights of all the animals were recorded 
on 'day 1 ' and 'day 61 ' of the experiment, and compared. ${ }^{17}$

\section{Biochemical estimations for lipids}

The parameters of lipid profile which were observed were as follows:

\author{
1. Total Serum Cholesterol ${ }^{18}$ \\ 2. Serum Triglycerides ${ }^{19}$ \\ 3. High Density Lipoprotein (HDL) Cholesterol $^{20}$ \\ 4. Low Density Lipoprotein (LDL) Cholesterol ${ }^{21}$
}

LDL-cholesterol was measured by using the following formula:

LDL Cholesterol $=\quad$ Total Cholesterol - HDL Cholesterol $-\frac{\text { Triglyceride }}{5}$

\section{Atherogenic Index 22}

The atherogenic index was calculated using the following formula:

$$
\text { Atherogenic Index }=\frac{\text { Total Cholesterol - HDL }}{\text { HDL }}
$$

\section{Biochemical estimations for antioxidant activity of plant extracts}

\section{Enzymatic assay of catalase}

Catalase activity was measured in blood on day ' 1 ' and day ' 61 ' of the experiment by continuous spectrophotometric rate determination by Beers and Sizer method. ${ }^{23}$ The values were expressed as $\mu \mathrm{mol}$ of $\mathrm{H}_{2} \mathrm{O}_{2} / \mathrm{min} / \mathrm{ml}$.

\section{Estimation of Serum Malondialdehyde (MDA)}

MDA level was measured on day ' 1 ' and day ' 61 ' of the experiment by colorimeter as described by Satoh K. ${ }^{24}$

\section{Statistical analysis}

The results were statistically analysed using One-way ANOVA followed by Dunnett's multiple comparison test. The Student's ' $t$ ' test (Paired) was done to compare the body weights of the rats before (on $1^{\text {st }}$ day) and after (on $61^{\text {st }}$ day) drug administration. The statistical analysis was done using computerized Graph Pad Prism Software version 5.00. Values of $\mathrm{p}<0.05$ were considered significant.

\section{RESULTS}

\section{Acute toxicity test}

Of all the five animals administered $2000 \mathrm{mg} / \mathrm{kg}$ of the extract, no mortality was recorded. Therefore, the LD50of the extract was considered to be above $2000 \mathrm{mg} / \mathrm{kg}$.

\section{Phytochemical analysis}

Preliminary phytochemical analysis of EESKCB indicated the presence of alkaloids, phenols, flavonoids, saponins, tannins, glycosides, carbohydrates (reducing sugars), proteins, triterpenoids and phytosterols.

\section{Effect of EESKCB on serum lipids and atherogenesis in rats fed with high fat diet}

The statistical analysis of the data was done using OneWay Anova followed by Dunnett's Multiple Comparison Test.

It was seen that at the end of 8 weeks following administration of high fat diet in the rats, there was a significant $(p<0.05)$ increase in all the lipid parameters including the atherogenic index of the rats as compared to the Normal Control Group. However, there was a significant $(\mathrm{p}<0.05)$ decrease in the serum levels of high density lipoprotein cholesterol as a result of high fat diet administration. It was also seen that concomitant administration of EESKCB $(200 \mathrm{mg} / \mathrm{Kg})$ and standard drug Simvastatin $(1.8 \mathrm{mg} / \mathrm{Kg})$ along with high fat diet in the Hyperlipidemic test and Hyperlipidemic standard groups respectively, resulted in a significant $(p<0.05)$ decrease in all the lipid parameters and atherogenic index along with a significant $(\mathrm{p}<0.05)$ rise in the value of serum high density lipoprotein cholesterol. The percentage of increase of serum high density lipoprotein (HDL) cholesterol in Hyperlipidemic test and Hyperlipidemic standard was $136.36 \%$ and $209.09 \%$ respectively as compared to Hyperlipidemic control. In fact, the standard drug and EESKCB raised serum levels of HDL cholesterol levels to more than the serum level of HDL seen in the rats belonging to the Normal control group. The percentage of reduction of serum cholesterol, serum triglyceride, serum low density lipoprotein cholesterol and atherogenic index in the Hyperlipidemic test Group as compared to Hyperlipidemic control are 57.32\%, 65.44\%, 67.03\% and $85.91 \%$ respectively (Table 1 ).

\section{Effect on changes in body weight}

Student's ' $t$ ' test (Paired) was used to compare the body weights of the rats before (on Day 1) and after (on Day 61) drug administration.

The final body weight on Day 61 showed significant $(p<0.05)$ increase from the initial body weight in all the groups, with the Hyperlipidemic Control Group showing the maximum percentage of increase in body weight (Table 2).

\section{Effect on serum catalase and malondialdehyde (MDA) levels in diabetic rats}

One-way ANOVA followed by Dunnett's multiple comparison test was used to analyse the data statistically. On Day 1 of the experiment, there was no significant 
difference $(p>0.05)$ in serum levels of MDA and catalase among the different groups. However, on Day 61 of the experiment, the Hyperlipidemic Control Group showed a significant decrease $(\mathrm{p}<0.05)$ in serum levels of catalase and a significant increase $(\mathrm{p}<0.05)$ in serum levels of MDA as compared to the Normal control group.

Table 1: Effect of EESKCB on serum lipids at the end of 8th week of experiment.

\begin{tabular}{|c|c|c|c|c|c|}
\hline \multirow{2}{*}{ Groups } & \multicolumn{4}{|c|}{ Test result (mg/100ml) } & \multirow{2}{*}{$\begin{array}{l}\begin{array}{l}\text { Test result } \\
\text { (in ratio) }\end{array} \\
\text { Atherogenic } \\
\text { index }\end{array}$} \\
\hline & $\begin{array}{l}\text { Serum total } \\
\text { cholesterol }\end{array}$ & $\begin{array}{l}\text { Serum } \\
\text { triglycerides }\end{array}$ & $\begin{array}{l}\text { Serum high } \\
\text { density lipoprotein }\end{array}$ & $\begin{array}{l}\text { Serum low density } \\
\text { lipoprotein }\end{array}$ & \\
\hline Normal control & $72 \pm 1.98$ & $68 \pm 1.73$ & $23 \pm 1.77$ & $35 \pm 1.57$ & $2.13 \pm 0.04$ \\
\hline Hyperlipidemic control & $239 \pm 2.05^{\mathrm{a}}$ & $217 \pm 1.86^{\mathrm{a}}$ & $11 \pm 2.03^{a}$ & $185 \pm 1.75^{\mathrm{a}}$ & $20.73 \pm 1.26^{\mathrm{a}}$ \\
\hline Hyperlipidemic test & $\begin{array}{l}102 \pm 3.50^{\mathrm{b}} \\
(57.32 \%)\end{array}$ & $\begin{array}{l}75 \pm 1.77^{\mathrm{b}} \\
(65.44 \%)\end{array}$ & $\begin{array}{l}26 \pm 1.86^{\mathrm{b}} \\
(136.36 \%)\end{array}$ & $\begin{array}{l}61 \pm 1.79^{b} \\
(67.03 \%)\end{array}$ & $\begin{array}{l}2.92 \pm 0.41^{\mathrm{b}} \\
(85.91 \%)\end{array}$ \\
\hline $\begin{array}{l}\text { Hyperlipidemic } \\
\text { standard }\end{array}$ & $\begin{array}{l}75 \pm 2.30^{b} \\
(68.62 \%)\end{array}$ & $\begin{array}{l}59 \pm 1.79^{b} \\
(72.81 \%)\end{array}$ & $\begin{array}{l}34 \pm 1.88^{\mathrm{b}} \\
(209.09 \%)\end{array}$ & $\begin{array}{l}29 \pm 1.63^{\mathrm{b}} \\
(84.32 \%)\end{array}$ & $\begin{array}{l}1.21 \pm 0.32^{b} \\
(94.16 \%)\end{array}$ \\
\hline $\mathrm{F}$ & 916.5 & 1763 & 25.51 & 1870 & 188.2 \\
\hline ANOVA & 3,20 & 3,20 & 3,20 & 3,20 & 3,20 \\
\hline $\mathrm{p}$ & $<0.05$ & $<0.05$ & $<0.05$ & $<0.05$ & $<0.05$ \\
\hline
\end{tabular}

Values are expressed as MEAN \pm SEM ( $n=6$ ). One Way ANOVA followed by Dunnett's Multiple Comparison test is done. ${ }^{\mathrm{a}} \mathrm{p}<0.05$, when compared to the Normal control Group. ${ }^{b} \mathrm{p}<0.05$, when compared to the Hyperlipidemic control Group.

Table 2: Effects of EESKCB on body weights in the rats.

\begin{tabular}{|c|c|c|c|c|}
\hline \multirow{2}{*}{ Groups } & \multicolumn{4}{|c|}{ Body Weights in grams (g) } \\
\hline & Initial ( $1^{\text {st }}$ Day $)$ & Final (61 ${ }^{\text {st }}$ Day) & Change & \%of Increase \\
\hline Normal control & $200 \pm 17.09$ & $257 \pm 15.72^{\mathrm{a}}$ & $57 \pm 2.53$ & 29.00 \\
\hline Hyperlipidemic control & $225 \pm 7.07$ & $315 \pm 8.18^{\mathrm{a}}$ & $90 \pm 2.86$ & 40.00 \\
\hline Hyperlipidemic test & $222 \pm 7.89$ & $292 \pm 9.52^{\mathrm{a}}$ & $71 \pm 2.79$ & 32.00 \\
\hline Hyperlipidemic standard & $224 \pm 6.32$ & $279 \pm 6.29^{\mathrm{a}}$ & $55 \pm 2.00$ & 25.00 \\
\hline $\mathrm{F}$ & 1.244 & 5.397 & 40.32 & \\
\hline ANOVA & 3,20 & 3,20 & 3,20 & \\
\hline $\mathrm{p}$ & $>0.05$ & $<0.05$ & $<0.05$ & \\
\hline
\end{tabular}

Data represented as Mean \pm SEM; $n=6$ rats in each group. One-way ANOVA and Student's t-test (Paired) done. ${ }^{a} \mathrm{p}<0.05$ when compared to the Initial body weight.

Table 3: Effect on serum catalase and malondialdehyde (MDA) levels in rats.

\begin{tabular}{|c|c|c|c|c|}
\hline \multirow{2}{*}{ Groups } & \multicolumn{2}{|c|}{ Catalase $(\mu \mathrm{mol} / \mathrm{min} / \mathrm{ml})$} & \multicolumn{2}{|c|}{ Malondialdehyde (MDA) (nmol/ml) } \\
\hline & Day 1 & Day 61 & Day 1 & Day 61 \\
\hline Normal Control & $30.5 \pm 1.54$ & $35 \pm 1.88$ & $3.4 \pm 0.17$ & $4.35 \pm 0.16$ \\
\hline Hyperlipidemic Control & $32.0 \pm 1.63$ & $11.73 \pm 1.68^{\mathrm{a}}$ & $3.02 \pm 0.14$ & $14.38 \pm 0.20^{\mathrm{a}}$ \\
\hline Hyperlipidemic Test & $31.6 \pm 1.26$ & $24.33 \pm 2.20^{\mathrm{b}}$ & $3.5 \pm 0.16$ & $6.41 \pm 0.24^{\mathrm{b}}$ \\
\hline Hyperlipidemic Standard & $33.3 \pm 1.71$ & $27.53 \pm 2.46^{\mathrm{b}}$ & $3.6 \pm 0.19$ & $9.03 \pm 0.23^{b}$ \\
\hline $\mathrm{F}$ & 0.57 & 21.83 & 2.62 & 438.9 \\
\hline ANOVA & 3,20 & 3,20 & 3,20 & 3,20 \\
\hline $\mathrm{p}$ & $>0.05$ & $<0.05$ & $>0.05$ & $<0.05$ \\
\hline
\end{tabular}

Values are Mean \pm SEM; $n=6$ rats in each group. One-way ANOVA followed by Dunnett's multiple comparison test was done. ${ }^{\mathrm{a}} \mathrm{p}<0.05$ when compared to Normal Control Group. ${ }^{b} \mathrm{p}<0.05$ when compared to Hyperlipidemic Control Group.

Administration of EESKCB and Simvastatin consecutively for eight weeks, caused a significant increase $(\mathrm{p}<0.05)$ in catalase levels and significant decrease $(p<0.05)$ in MDA levels in the test drug and standard drug groups respectively, as compared to the Hyperlipidemic Control group (Table 3 ).

\section{DISCUSSION}

In the study, it was seen that continuous administration of high fat diet upto 8 weeks to Hyperlipidemic controls rats showed significant $(\mathrm{p}<0.05)$ increase in total cholesterol, triglyceride, LDL cholesterol and atherogenic index while 
showing a significant $(\mathrm{p}<0.05)$ decrease in the level of HDL cholesterol.

High fat diet brings about an increase in lipid parameters by increasing intestinal absorption of lipids, increasing hepatic lipogenesis, increasing fatty acid synthesis and reducing lipolysis in peroxisomes. ${ }^{25}$ Increased levels of blood cholesterol is a major risk factor for coronary heart disease whereas increased HDL is cardioprotective. ${ }^{26}$ Increased atherogenic index is another high risk factor for coronary artery disease. ${ }^{27}$ Increased levels of LDL cholesterol also poses an atherosclerotic risk as LDL gets oxidised to form foam cells which get deposited in the arterial wall as atherosclerotic plaque. ${ }^{28}$

In the present study, concurrent administration of EESKCB with high fat diet showed significant $(p<0.05)$ decrease in all the lipid parameters except HDL which showed a significant $(\mathrm{p}<0.05)$ rise as compared to the Hyperlipidemic control group.

Phytochemical analysis of the EESKCB conducted in the present study revealed the presence of alkaloids, phenols, flavonoids, saponins, tannins, triterpenoids etc. The lipid lowering action of the extract may be due to the presence of triterpenoids, polyphenols, flavonoids and saponins in it. Flavonoids have been reported to exert hypocholesterolemic action by inhibiting HMG-CoA reductase activity, inhibiting cellular cholesterol esterification, triacylglycerol and phospholipids synthesis and inhibiting the secretion of apo B from the liver. ${ }^{29}$ Flavonoids also inhibit the oxidation of LDL cholesterol to form foam cells and thus exert protective effects. ${ }^{30}$ It has also been reported that triterpenoids and flavonoids have lipoprotein lipase releasing activity. ${ }^{31}$ Sitosterol, constituent of seed kernel of Caesalpinia bonducella, has been reported to possess hypocholesterolemic action by inhibiting the intestinal absorption of cholesterol and accelerating the catabolism of cholesterol to bile acid..$^{6,32}$

Hyperlipidemia caused by high fat diet leads to the generation of reactive oxygen species (ROS) by increased activation of NADPH oxidase, increased $\beta$ oxidation of free fatty acid in mitochondria, increased NF- $\kappa \beta$ signalling and dysregulated production of adipocytokinins. ${ }^{33}$ This enhanced production of ROS leads to oxidative stress which in turn contributes to vascular changes, endothelial dysfunction, thrombosis and atherosclerosis. ${ }^{34}$ The serum catalase and malondialdehyde (MDA) assays conducted in the present study showed an increase in the levels of plasma lipid peroxidation product, MDA and a reduction in the levels of antioxidant defense enzyme catalase in the Hyperlipidemic control Group; thereby signifying the occurrence of oxidative stress. However, administration of the test drug caused a decrease in the serum levels of MDA and an increase in the levels of catalase in the animals of the Test drug Group. This showed that the extract has antioxidant property, and this might be because of the presence of phytochemicals like flavonoids and triterpenoids in it. Flavonoids directly scavenge free radicals by acting as chain-breaking anti-oxidants or they help in recycling other chain-breaking anti-oxidants as well. They also prevent the formation of free radicals by inhibiting several pro-oxidant enzymes like lipooxygenase. ${ }^{30}$ Triterpenoids cause an increase in the content of transcription factor, nuclear factor- erythroid-2related factor 2 (Nrf2) and thereby increases the expression of it's target gene products like catalase. Triterpenoids also decrease the expression of Nuclear factor kappa $\beta(\mathrm{NF} \kappa \beta)$ and thus contributes to attenuation of oxidative stress. ${ }^{35}$

In this study, administration of high fat diet to the rats for 60 days resulted in an increase in their body weights. An increased consumption of high fat diet causes a change in the composition of the intestinal microbial community which promotes hepatic lipogenesis and enhances lipoprotein lipase directed incorporation of triglycerides into adipocytes; this in turn increases body weight and obesity. ${ }^{36}$ The extract inhibited the gain in body weight probably by restoring the composition of the gut microflora and thereby inhibiting hepatic lipogenesis and lipoprotein lipase activity.

Thus, although the exact mechanism for the hypolipidemic action of seed kernel of Caesalpinia bonducella remains unknown, it can be presumed that the presence of medicinally important phytochemicals and antioxidants in the seed kernel of Caesalpinia bonducella, is responsible for its lipid lowering activity. However, further studies to find out the exact mechanism of hypolipidemic action and to elucidate the active principle responsible for the hypolipidemic action can be carried out.

\section{ACKNOWLEDGEMENTS}

Authors would like to thank to Dr. L. R. Saikia, Professor, Department of Life Sciences, Dibrugarh University, Dibrugarh for helping them with the taxonomical identification of the plant. Authors are also thankful to $\mathrm{Mr}$. Bipul Thakuria and Mr. Michikanta Mech, Department of Pharmacology, Assam Medical College and Hospital, Dibrugarh for helping them during their research work.

Funding: No funding sources

Conflict of interest: None declared

Ethical approval: The study was approved by the Institutional Animal Ethics Committee (634/02/a/CPCSEA)

\section{REFERENCES}

1. Ghule BV, Ghante MH, Saoji AN, Yeole PG. Hypolipidemic and Antihyperlipidemic Effects of LageneriaSiceraria (Mol.) Fruit Extracts. Indian Journal of Experimental Biology. 2006 Nov;44:905-9.

2. Nirosha K, Divya M, Vamsi S, Sadiq M. A Review On Hyperlipidemia. International $\mathbf{J}$ of Novel Trends in Pharmaceutical Sciences. 2014 Sep;4(5):81-92.

3. Tripathi KD. Essentials of Medical Pharmacology. $7^{\text {th }}$ Ed. New Delhi: Jaypee Brothers Medical Publishers 
(P) Ltd; Chapter 45, Hypolipidaemic Drugs and Plasma Expanders; 2013:634-646.

4. Eldalo AS, Alotaibi MN, Alenazi TO, Albogami HA, Mohamed KM. Use of Herbal Medicines in the Treatment of Obesity in Taif, Saudi Arabia. Saudi Journal of Medicines and Medical Sciences. 2017 May-Aug;5(2):149-54.

5. Kirtikar KR, Basu BD. Indian medicinal plants. $2^{\text {nd }}$ Ed. Dehradun: International Book Distributors; Caesalpiniaceae; 1988:839-902.

6. Kakade NR, Pingale SS, Chaskar MG. Phytochemical and Pharmacological Review of Caesalpinia bonducella. International Research $\mathbf{J}$ of Pharmacy. 2016;7(12):12-7.

7. Nairn JG. Solutions, emulsions, suspensions and extracts. In: Gennaro A, Marderosian AD, Hanson GR, Medwick T, Popovich NG, Schnaare RL, Schwartz JB, White HS, editors. Remington: the science and practice of pharmacy. $20^{\text {th }}$ Ed Philadelphia: Lippincott Williams and Wilkins; 2000:721-752.

8. Tiwari P, Kumar B, Kaur M, Kaur G, Kaur H. Phytochemical Screening and Extraction: A Review. Internationale Pharmaceutica Sciencia. 2011 JanMar;1(1):98-106.

9. Organization for Economic Cooperation and Development (OECD). OECD Guidelines for Testing of Chemicals. France: OECD Publications; Section 4: Health Effects. Test No. 425: Acute Oral Toxicity: Up-and-Down Procedure; [cited 2017 Aug 15]; 2008:1-27. Available at: http://www.oecdilibrary.org/environment/oecd-guidelines-for-thetesting-of-chemicals-section-4-healtheffects_20745788

10. Muddapur UM, More S, Karekar T, Mungi H, Thakkannavar S, Savadatti N. Evaluation of acute and sub-acute toxicity effect of ethanol extract from Caesalpinia bonducella seed kernel. Journal of Pharmacognosy and Phytochemistry. 2014;3(3):1204.

11. Sarma G, Das S. Hypoglycemic Action of Seed Kernel of Caesalpinia bonducella Fleming In Normal and Alloxan- Induced Diabetic Albino Rats. The Internet Journal of Pharmacology. [cited 2017 Sep 27]; 2008:6(2). Available at: http://www.ispub.com/IJPHARM/6/2/9635

12. Shyamala MP, Venukumar MR, Latha MS. Antioxidant potential of the Syzygiumaromaticum (Gaertn.) Linn. (cloves) in rats fed with high fat diet. Indian J of Pharmacology. 2003;35:99-103.

13. Jain GC, Jhalani S, Agarwal S, Jain K. Hypolipidemic and antiatherosclerotic effect of Leptadeniapyro technica extract in cholesterol fed rabbits. Asian J Exp Sci. 2007;21(1):115-22.

14. Bhardwaj LK, Chandrul KK, Sharma US. Evaluation of anthelmintic activity of Caesalpinia crista linn. Seed extracts. World Journal of Pharmacy and Pharmaceutical Sciences. 2016;5(2):976-82.
15. Ghosh MN. Fundamentals of experimental pharmacology. 6th ed. Kolkata: Hilton and Company. Chapter 30, Toxicity testing; 2015:171-178.

16. Ghosh MN. Fundamentals of experimental pharmacology. 6th ed. Kolkata: Hilton and Company. Chapter 2, Some standard techniques; 2015:14-17.

17. Choi HK, Won EK, Jang YP, Choung SY. Antiobesity Effect of Codonopsislanceolatain HighCalorie/High-Fat-Diet-Induced Obese Rats. EvidenceBased Complementary and Alternative Medicine; 2013:1-9. Available at: https://www.hindawi.com/journals/ecam/2013/21029 7/http://dx.doi.org/10.1155/2013/210297

18. Allain CC, Poon LS, Chan CG, Richmond W, Fu PC. Enzymatic determination of total serum cholesterol. Clin Chem. 1974;20(4):470-5.

19. Fossati P, Prencipe L. Serum triglycerides determined colorimetrically with an enzyme that produce hydrogen peroxide. Clin Chem. 1982 Oct 1;28(10):2077-80.

20. Izzo C, Grillo F, Murador E. Improved method for determination of high-density-lipoprotein cholesterol I.Isolation of high-density lipoproteins by use of polyethylene glycol 6000. Clin Chem. $1981 ; 27(3): 371-4$.

21. Friedewald WT, Levy RI, Fredrickson DS. Estimation of the concentration of low-density lipoprotein cholesterol in plasma, without use of the preparative ultracentrifuge. Clin Chem. 1972;18(6):499-502.

22. Schulpis K, Karikas GA. Serum cholesterol and triglyceride distribution in 7767 School-aged Greek children. Paediatrics. 1998 May;101(5):861-4.

23. Beers RF, Sizer IW. A spectrophotographic method for measuring the breakdown of hydrogen peroxide by catalase. J Biol Chem. 1952;195:133-40.

24. Satoh K. Serum lipid peroxide in cerebrovascular disorders determined by a new colorimetric method. Clinica Chimica Acta. 1978 Nov 15;90(1):37-43.

25. Jurgonski A, Juskiewicz J, Zdunczyk Z. A High-Fat Diet Differentially Affects the Gut Metabolism andBlood Lipids of Rats Depending on the Type of Dietary Fatand Carbohydrate. Nutrients. 2014;6:61626.

26. Castelli WP. Lipids, risk factors and ischaemic heart disease. Atheroslerosis. 1996;124:S1-9.

27. Ikewuchi CJ, Ikewuchi CC. Alteration of Plasma Lipid Profile and Atherogenic Indices of Cholesterol Loaded Rats by Tridax Procumbens Linn: Implications for the Management of Obesity and Cardiovascular Diseases. Biokemistri. 2009 Dec;21(2):95-9.

28. Sharma HL, Sharma KK. Sharma and Sharma's Principles of Pharmacology. 3rd ed. New Delhi: Paras Medical Publisher; Chapter 23, Drug Therapy of Dyslipidaemia; 2017:328-343.

29. Theriault A, Wang Q, Van Iderstine SC, Chen B, Franke AA, Adeli K. Modulation of hepatic lipoprotein synthesis and secretion by taxifolin, a plant flavonoid. Journal of Lipid Research. 2000;41:196979. 
30. Wilcox LJ, Borradaile NM, de Dreu LE, Huff MW. Secretion of hepatocyte apo B is inhibited by the flavonoids, naringenin and hesperetin, via reduced activity and expression of ACAT 2 and MTP. Journal of Lipid Research. 2001;42:725-34.

31. Kumarappan CT, Rao TN, Mandal SC. Polyphenolic extract of Ischnocarpus frustescens modifies hyperlipidemia status in diabetic rats. Journal of Cell and Molecular Biology. 2007;6(2):175-87.

32. Ya-Mei Y, Chien-Hsi W, Yueh-He T, Chingmin ET, Weng-Cheng C. Antioxidative and hypolipidemic effects of Barley leaf essence in a rabbit model of atherosclerosis. Jpn J Pharmacol. 2002;89:142-8.

33. Kesh SB, Sarkar D, Manna K. High-Fat Diet-Induced Oxidative Stress and its impact on metabolic Syndrome: A Review. Asian Journal of Pharmaceutical and Clinical Research. 2016;9(1):4752.

34. Ohara Y, Peterson TE, Harrison DG. Hypercholesterolemia Increases Endothelial
Superoxide Anion Production. The J of Clinical Investigation, Inc. 1993 Jun;91:2546-51.

35. Aminzadeh MA, Reisman SA, Vaziri ND, Khazaeli M, Yuan J, Meyer CJ. The synthetic triterpenoid RTA dh404 (CDDOdhTFEA)restores Nrf2 activity and attenuates oxidative stress, inflammation, and fibrosis in ratswith chronic kidney disease. Xenobiotica. 2014;44(6):570-8.

36. Backhed F, Ding H, Wang T, Hooper LV, Koh GY, Nagy A, et al. The gut microbiota as an environmental factor that regulates fat storage. PNAS. 2004 Nov;101(44):15718-23.

Cite this article as: Sarma G, Das S. The hypolipidemic activity of ethanolic extract of seed kernel of Caesalpinia bonducella fleming on serum lipids and atherogenesis in albino rats fed with high fat diet. Int J Basic Clin Pharmacol 2018;7:266-72. 